\title{
Determinants of fishery and aquaculture products consumption at home in the EU28
}

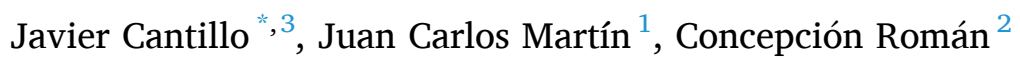 \\ Institute of Tourism and Sustainable Economic Development, Universidad de Las Palmas de Gran Canaria, Las Palmas de Gran Canaria, Spain
}

\section{A R T I C L E I N F O}

\section{Keywords:}

Fishery and aquaculture products

European residents' consuming behaviour

Frequency of consumption at home

Heteroscedastic Ordered Probit Model

Food policy

\begin{abstract}
A B S T R A C T
The European Union (EU) is the world's largest market for fishery and aquaculture products (FAPs) in nominal terms. Given the importance of these products, EU authorities and policy-makers are continuously monitoring consumer preferences and attitudes, analysing whether or not the implementation of EU policies and regulations improves the market conditions. For example, the Eurobarometer (European Union, 2018a) surveyed 27,732 EU residents including a specific module to analyse the fishery and aquaculture EU market. In this study, the dataset is used to estimate Ordered Probit models using effects coding and their marginal effects to identify the main determinants of the frequency of FAPs at-home consumption. Results indicate that the highest probability to consume more frequently FAPs is related to considering that one of the main reasons for buying or eating fishery and aquaculture products is because they are healthy, while the highest probability to consume less frequently FAPs is related to consumers who do not understand at all the information accompanying the products. Similarly, other important reasons for consuming FAPs more frequently are their good taste and low relative price. Also, results indicate a higher frequency of consumption of FAPs for those consumers who are over 55 years of age, are wealthy, have a wild product preference, live in a household of 3 persons or more and are very satisfied with their lives. To our best knowledge, there is not a similar approach in the current literature that considers such an extensive sample which is representative of all the countries that conform the EU28. Results provide valuable information especially for producers and authorities in terms of marketing and policy analysis.
\end{abstract}

\section{Introduction}

The EU is the world's largest trader of fishery and aquaculture products (FAPs) in nominal terms reaching around EUR 30.3 billion in 2017 and surpassing second-ranked China by more than EUR 2.3 billion (FAO, 2018). These high figures are a consequence of the importance of FAPs for the human diet, accounting for around $17 \%$ of the intake of animal protein for the global population (FAO, 2018), and more specifically, because of the many benefits offered by the consumption of these products. In fact, according to FAO (n.d.), fish is not only a source of protein and healthy fats but also an exceptional source of nutrients, fatty acids, iodine, vitamin D and calcium. The importance of FAPs is also due to the consumption patterns of European residents, as according to data from 2016, the EU seafood average global consumption per capita of $24.33 \mathrm{~kg}$. (European Union, 2018b) was higher than the global consumption value of $20.3 \mathrm{~kg}$ (FAO, 2018). Additionally, for European residents, home is the most common place to consume the FAPs with $70 \%$ of consumers eating them at home at least once a month and $41 \%$ at least once a week (European Union, 2018a).

Given the importance of FAPs, some EU regulations, framed into two different sections: Common Fisheries Policy (CFP) and Common Market Organisation (CMO), have become an indispensable instrument for the appropriate functioning of the market and industry (D'Amico et al., 2016). The CFP consists of a set of rules for the management of the fishing fleets and the market of FAPs, as well as for the conservation of fish stocks (European Union, 2018a). Meanwhile, the CMO ensures that consumers receive more and better information for FAPs sold in the European market, with the same rules applying regardless of their origin (European Commission, 2016). The CMO is currently regulated by the $1379 / 2013$ EU regulation, which amongst other things, establishes the

\footnotetext{
* Corresponding author.

E-mail addresses: javier.cantillo101@alu.ulpgc.es (J. Cantillo), jcarlos.martin@ulpgc.es (J.C. Martín), concepcion.roman@ulpgc.es (C. Román).

1 https://orcid.org/0000-0002-2950-2405

2 https://orcid.org/0000-0002-0591-1298

3 https://orcid.org/0000-0002-5442-3960
} 
mandatory labelling information for FAPs (D'Amico et al., 2016) and a list of the voluntary information that can be added to FAPs, such as information related to the environmental, ethical or social aspects of the products, production techniques and practices, and others (European Parliament, 2013).

The European Commission aims to accurately develop and implement changes to the commented regulations. Thus, it is important to know the state of the fisheries and maritime industry as well as the opinions of citizens and stakeholders (European Union, 2018a). The understanding of consumers' habits and attitudes is necessary to better address their appropriate implementation and the potential foreseen changes. For example, the success of the CMO requires consumers to be able to understand the information of labels, the necessity and benefits of eating fish and the nutritional properties of different species available in the market. The European Parliament (2013) advised the Member States to invest in marketing and educational campaigns aiming to increase FAPs consumption. The European Commission (2017) found a total of 685 FAPs promotional campaigns and projects in the period 2007-2015 in 26 EU Member States, and only two Member States (Austria and Luxembourg) have not carried out any campaigns. In our view, the campaigns should be customized to the preferences and attitudes of consumers. A better understanding of the internal market of FAPs allows operators to raise their competitiveness and to adopt new strategies or to modify their current ones based on consumers' demands, to pursue the strengthening and growth of the internal market and, as a result, to stimulate the creation of jobs (European Union, 2018a).

Despite the importance of knowing FAPs' preferences and habits of European consumers, most of the previous econometric models are only focused on a particular geographical context (specific city, region, or country). The literature is not scant as many papers have analysed the socio-demographic and economic factors as well as other individual and attitudinal factors as the main determinants of FAPs' consumption frequency. Nevertheless, to our knowledge, the previous studies are more limited in several aspects such as the sample representativeness and the number of determinants studied. From the methodological perspective, the study is also novel as Ordered Probit models in the context of FAPs consumption are still scarce (Lee and Nam, 2019).

In our view, the success or updating of the current conditions of EU policies depends more on a better understanding of FAPs' consumption across the EU. Thus, the present study aims to fill this important gap, analysing the main determinants that explain at-home FAPs' consumption frequency in the EU through the use of an Ordered Probit model. This type of model permits to analyse the consumers' preferences in an effective way (Kumar et al., 2008; Quagrainie, 2006). Concretely, we use a representative sample of the EU to analyse one of the most extensive lists of determinants that have been used to date. The determinants used in the study are: demographic factors (country of residence, age, place of living and household-size), economic factors (difficulties in paying the bills and society class) and individual and attitudinal factors (wildcaught preference, easiness and clearness to understand FAPs' information, main reasons for buying or eating FAPs, important aspects when buying FAPs, expectations of life conditions in five years and life satisfaction).

Besides other prerogatives, it is important to identify the main determinants that affect the frequency of consumption of these products because it is well known that consumers who purchase seafood more frequently are willing to pay higher prices than those who purchase it less frequently (Quagrainie, 2006). For this reason, marginal effects will be estimated to determine which are the most important factors or attitudes that increase the probability of consuming FAPs at home at least once a week. The results provide important insights for stakeholders in the fisheries and aquaculture sector on the factors and attitudes that should be highlighted in the marketing campaigns and information accompanying the products. Additionally, the results of the marginal effects may also be valuable for researchers, academics, and authorities to propose policy lessons or to guide the scope of future investigations.
The remainder of the paper is organized as follows: Section 2 offers some insights from the literature, section 3 presents some information about the database, section 4 describes the methodology, section 5 details the results, section 6 discusses the results and section 7 offers some concluding remarks.

\section{Literature review}

The literature shows that the preference for FAPs can be studied by analysing their frequency of consumption or the choices of consumers. While both types of investigations provide information on the patterns of consumption for these products, the choice-base studies usually focus more on the general preferences and the willingness to pay estimates for these products, while the studies analysing the frequency of consumption aim to identify the factors or attitudes that enhance the repetition of the action of consuming or buying these products. The present investigation is in the context of the second type.

The literature shows different approaches that determine the main factors affecting the frequency of consumption of diverse seafood products, such as the Ordered Probit models (Almendarez-Hernández et al., 2017; Kumar et al., 2008; Lee and Nam, 2019; Myrland et al., 2000; Terin, 2019; Thong and Solgaard, 2017), the ordered logit models (Almendarez-Hernández et al., 2017; Santeramo et al., 2017), the theory of planned behaviour as a conceptual framework (Higuchi et al., 2017; Thong and Olsen, 2012; Tomić et al., 2016; Tuu et al., 2008; Verbeke and Vackier, 2005; Yousuf et al., 2019), the structural equation models (Rortveit and Olsen, 2009, 2007); some regression models such as the ordinary least square regression (Cavaliere et al., 2019), the logistic regression model (Herrmann et al., 1994), the multiple linear regression (Can et al., 2015) and the hierarchical regression models (Hall and Amberg, 2013); and other statistical analyses such as ANOVA (Almeida et al., 2015), frequency distribution (Islam et al., 2018) and Spearman's correlations (Murray et al., 2017).

Focusing on the studies that used ordered probit models, Lee and Nam (2019) studied the determinants of the frequency of live fish consumption in South Korea. They found that respondents with a low price elasticity of demand and who consider safety to be a more important factor than the price are likely to consume live fish more frequently; whereas preference for wild-caught fish was relevant in consumers' choices, but not in their consumption frequency. Similarly, Thong and Solgaard (2017) determine how psychological and socio-demographic variables have an impact on the frequency of consumption of fish, shrimp and mussels in France. Results indicate that female, elderly, high-income consumers, living with children, living with family or partner tend to consume seafood more frequently, but there may be some differences depending on the seafood product being considered. In addition, the most important positive driver was weight control among the nine reasons assessed for the frequency of fish consumption, while convenience was the most relevant barrier. Almendarez-Hernández et al. (2017) assessed the frequency of consumption of tuna in Mexico and found that the marginal effects decreased as income increased. They also found that consumers who prefer canned tuna have a lower frequency of consumption compared to those who prefer fresh tuna; however, consumers who have been informed about the 'dolphin-safe' eco-label are more eager to consume canned tuna. Kumar et al. (2008) identified factors affecting the frequency of purchases of farmed catfish by consumers in the United States. Results indicate that fresh catfish buyers are more likely to purchase them more frequently than those who buy frozen catfish. Married couples, and Caucasian and African Americans were also more eager to buy catfish more frequently. Myrland et al. (2000) designed a recursive sequential model of the decision-making process for the consumption of seafood at home in Norway. The methodology included a set of ordered probit models, that showed that the attributes of the product are more important perceived barriers to consumption than price beliefs. They also found that consumption increases when individuals are older, have higher education or larger 
household size. Moreover, Terin (2019) studied how the frequency of fish consumption of households in Turkey is related to sociodemographic factors and attitudes, and found that consumers with higher incomes, with a higher number of children in the household, and where the householders consume other aquaculture products other than fish tend to have a higher frequency of consumption. In general, all the models found on these investigations consist mostly of ordered probit models with or without interaction effects, but none of them have considered the heteroscedasticity that might be present in the effects of the variables.

In general, the studies in the literature show some differences regarding the independent variables considered, the countries included in the analysis and the species evaluated. Moreover, only a few studies analysed the frequency of consumption at home separately (Almeida et al., 2015; Herrmann et al., 1994; Myrland et al., 2000), which might be appropriate given that there are differences between the significant factors affecting at home and outside-home consumption (Almeida et al., 2015; Herrmann et al., 1994).

The factors that affect the frequency of consumption of seafood can be grouped in economic, demographic and attitudinal factors (Herrmann et al., 1994). As far as economic and demographic factors are concerned (see Table 1 in the appendix), the results obtained from the literature do not lead to a robust and clear hypothesis regarding their frequency trends. Some of the observed differences may be due to the characteristics of the sample, the species studied, and the methodology used in the investigations. Thus, there are no general trends regarding the frequency of consumption of seafood products for the gender, age, household size, the presence of young children, the education level, the income, and the marital status factors. On the other hand, most studies suggest that women, older people, people with higher education, higher incomes, married or living with a partner and a higher social class tend to have a higher frequency of consumption of seafood products.

In addition, factors related to individual conditions or attitudes towards the attributes of seafood products present a more general frequency trend pattern (see Table 2 in the appendix). Thus, the positive drivers to a higher frequency of consumption are having a positive attitude towards seafood, considering important the low calories and low fat of the products, being satisfied with the safety of the products, being an expert judging the safety of the products, preferring fresh products, caring about eco-labels and environmental issues, being a regular consumer, being involved in recreational fishing activities, executing often physical activities, frequent consumption of seafood during childhood, high knowledge of the production of seafood and consumption of other products other than fish. Meanwhile, the main barriers are the price or cost, not purchasing wild seafood for environmental concerns, and being uncomfortable when cooking or preparing seafood.

Furthermore, factors related to familiarity, health and sensory qualities are largely dependent on the species of seafood examined. For familiarity, as expected, Hall and Amberg (2013) found that consumers who are familiar with aquaculture products tend to consume them more frequently, while Thong and Solgaard (2017) found different results about the familiarity factor for shrimp and mussels. Moreover, for the health attribute, most studies have agreed as expected that consumers who care about food-related health issues, consume FAPs more frequently. Seafood products, in general, are thought to be healthy, although Santeramo et al. (2017) found opposite results for the particular case of oysters, which consumption is explained more by being used to eat them, rather than by their healthy nature. Finally, as regards sensory qualities attributes, contrary to expectations, Santeramo et al. (2017) found that consumers who value oysters as tasty consume oysters less frequently, and the authors concluded that oysters are consumed for reasons other than their particular taste.

Other factors that have been analysed and affect the frequency of consumption of seafood products are the profession or occupation (Almendarez-Hernández et al., 2017; Can et al., 2015; Herrmann et al.,
1994; Lee and Nam, 2019), the living location (Herrmann et al., 1994; Islam et al., 2018; Lee and Nam, 2019; Myrland et al., 2000; Thong and Solgaard, 2017), the ethnic group (Kumar et al., 2008), the origin of the product (Kumar et al., 2008), the packaging presentation (Kumar et al., 2008), the type of store (Kumar et al., 2008), the preference for certain species (Lee and Nam, 2019), the nationality (Yousuf et al., 2019) and the seasonal period (Can et al., 2015).

\section{The database}

The database used to estimate the models was obtained from the Special Eurobarometer $2018^{4}$ (European Commission, 2019), which was the second survey on this topic and consisted of a block of questions that were asked in a similar survey conducted in 2016. The survey aimed to analyse the internal market for FAPs of the EU and to provide important information that helps stakeholders for the formulation of policies that might enhance the market.

The survey was conducted by the Kantar Public Brussels network at the request of the European Commission. The surveys were administered between June and July of 2018 in the 28 countries of the European Union. The interviews were made face to face at home and in the native language according to the country of residence. A total of 27,734 EU residents with different social and demographic characteristics were surveyed. In the electronic appendix, there is a table that presents the sample description that includes the countries involved, the frequency of surveys for each country and their respective percentage over the total sample (see Table EA1 in the electronic appendix).

The dependent variable in the current study is based on the responses for the frequency of consumption at home of FAPs, while the independent variables are related to the attitudes, economic and demographic factors of respondents. The answer format for the frequency of consumption at home goes from 1 to 5 , according to the frequency of consumption that varies from never (1) to at least once a week (5), respectively. The other levels are: less than once a year (2), several times a year but less than once a month (3) and at least once a month but less than once a week (4).

\section{Methodology}

The conceptual framework of the study assumes that the frequency of home consumption of FAPs is influenced by some economic and demographic consumers' characteristics and some attitudes that serve to approximate consumers' preferences toward the seafood products. Ordered Probit models were estimated to analyse the frequency of consumption at home for the mentioned products, by using it as a categorical and ordinal dependent variable. The Ordered Probit models are an appropriate analytical framework when survey responses are ordinal (Kumar et al., 2008; Thong and Solgaard, 2017).

The estimated probit models are rooted in the random utility modelling approach, and in them, it is assumed that the latent dependent variable $Y_{i}$ (home consumption frequency) depends on two elements: first, a linear combination of a vector of independent variables $X_{i}$ and the parameter vector $\theta$ that must be estimated; and second, an error term $\varepsilon_{i}$ that makes possible to elicit non-observed factors of the individual i. Equation (1) shows the latent regression model used.

$Y_{i}=\sum_{k=1}^{K} \theta_{i} X_{i}^{k}+\varepsilon_{i}$

Moreover, as the dependent variable in the former equation is not observable, it is measured by a set of indicators $y_{i}$ that represent the

\footnotetext{
4 The data can be publicly accessed in the webpage of the Leibniz Institute for the Social Sciences Data Archive for the Social Sciences (DAS): https://doi. org/10.4232/1.13212
} 
different categories of the dependent variable (Eq. 2), where $\mu_{1}, \mu_{2}, \mu_{3}$, $\mu_{4}$ and $\mu_{5}$ are category threshold parameters that must be estimated subject to $\mu_{1}<\mu_{2}<\mu_{3}<\mu_{4}<\mu_{5}$. These category thresholds indicate the points in which there is a variation in the level of consumption due to a high change in the latent preference.

Never: $y_{i}=1$ if $Y_{i} \leqslant \mu_{1}$

Less than one year: $y_{i}=2$ if $\mu_{1}<Y_{i} \leqslant \mu_{2}$

Several times a year but less than once a month: $y_{i}=3$ if $\mu_{2}<Y_{i} \leqslant \mu_{3}$

At least once a month but less than once a week: $y_{i}=4$ if $\mu_{3}<Y_{i} \leqslant \mu_{4}$

At least once a week: $y_{i}=5$ if $\mu_{4}<Y_{i}$

Given a distribution function for the error term, and setting $\mu_{0}=$ $-\infty$ and $\mu_{J}=\infty$, the probabilities for each of the outcomes can be obtained according to:

$$
\begin{gathered}
P\left(y_{i}=j\right)=P\left(\varepsilon_{i} \leqslant \mu_{j}-\theta X\right)-P\left(\varepsilon_{i} \leqslant \mu_{j-1}-\theta X\right)= \\
=F\left(\mu_{j}-\theta X\right)-F\left(\mu_{j-1}-\theta X\right)
\end{gathered}
$$

Where $\mathrm{F}$ is the assumed cumulative distribution function (cdf) for the error term, that in the case of the ordinal probit is the normal distribution.

The heteroscedastic model permits that the variance of the error term varies by allowing the standard deviation to be determined according to the following equation: $\sigma=\exp \left(\delta Z_{i}\right)$, where $Z_{i}$ is a vector of variables that explain the level of variance and $\delta$ is a vector of parameters to be estimated.

The parameters of the model are estimated by maximising the loglikelihood function according to:

$L(\theta, \delta, \mu)=\sum_{i=1}^{n} \sum_{j=1}^{J} I\left(y_{i}=j\right) \log \left(F\left(\frac{\mu_{j}-\theta X_{i}}{\exp \left(\delta Z_{i}\right)}\right)-F\left(\frac{\mu_{j-1}-\theta X_{i}}{\exp \left(\delta Z_{i}\right)}\right)\right)$

where $I\left(y_{i}=j\right)=1$ when consumer $i$ answers $j$ and 0 otherwise. The
Mannering, 2017; Fountas and Anastasopoulos, 2017); the observations can be differentiated by the use of a latent class model (Bago d'Uva, 2005; Fountas et al., 2018; Greene et al., 2008; Stone et al., 2019); the outcomes can be differentiated by the use of zero-inflated ordered probit models that accounts for some unobserved differentiation in one of the outcomes such as no-consumption vs. consumption or accidents with no injuries vs. accidents with injuries (Fountas et al., 2020; Jiang et al., 2017).

The independent explanatory variables considered in the models include dummies related to the country, age, place of living, household size, social class, wild product preference, attitudes regarding the main reasons for buying or eating FAPs, the most important aspects when buying FAPs, information regarding how easy and clear is to understand the information of the products, the difficulties of paying the bills, and life satisfaction and expectations. A table in the electronic appendix shows the questions of the survey that were used to obtain the information of the dependent and independent variables (see Table EA2 in the electronic appendix).

It is also important to note that, although there may be some similarities between the variables related to the main reasons for buying or eating FAPs and those related to the most important aspects of buying FAPs, there is a clear difference as the first category refers to both buying and eating behaviour while the second category refers only to buying behaviour.

For the present study, three ordered probit models were estimated: a homoscedastic model and two heteroscedastic models. Also, the marginal effects of the different consumption patterns at home were estimated. The marginal effects determine how much the probability of fish consumption at home outcome will be affected by a change in the value of the independent variables included in the model. In our study, the marginal effects can be calculated as follows as all the variables included in the model are binary or categorical:

$M E_{j}(X, Z)=\left(F\left(\frac{\mu_{j}-\theta \vec{X}_{1}}{\exp \left(\delta \vec{Z}_{1}\right)}\right)-F\left(\frac{\mu_{j-1}-\theta \vec{X}_{1}}{\exp \left(\delta \vec{Z}_{1}\right)}\right)\right)-\left(F\left(\frac{\mu_{j}-\theta \vec{X}_{0}}{\exp \left(\delta \vec{Z}_{0}\right)}\right)-F\left(\frac{\mu_{j-1}-\theta \vec{X}_{0}}{\exp \left(\delta \vec{Z}_{0}\right)}\right)\right)$

heteroscedastic ordered probit model is estimated by maximum likelihood estimation (MLE) and provides one of the basic extensions of the traditional ordered probit models that have been previously used in the context of fish consumption (Almendarez-Hernández et al., 2017; Kumar et al., 2008; Lee and Nam, 2019; Myrland et al., 2000; Terin, 2019; Thong and Solgaard, 2017). The basic idea of the traditional ordered probit model relies on the use of an unobserved latent variable through a mechanism based on a set of thresholds (Greene and Hensher, 2010; Winkelmann and Boes, 2009). However, both methods do not permit to analyse unobserved heterogeneity as one strict assumption is that the estimated parameters are considered fixed. The main limitations arise from considering that there exists a homogeneous process that generates the outcomes for all the observations (Fountas et al., 2020).

A number of model extensions that account for unobserved heterogeneity have been proposed in other research fields mainly in accident analysis. For example, the threshold parameters can depend on a set of explanatory variables (Avsar et al., 2017; Fountas and Anastasopoulos, 2018, 2017; Pudney and Shields, 2000); the coefficients can vary with the outcomes through fixed effects (Avsar et al., 2017; Cubas-Díaz and Martínez Sedano, 2018; Pfarr et al., 2010); the coefficients can vary with the observations through the use of random parameters (Behnood and
In the vectors $\mathrm{X}$ and $\mathrm{Z}$, the variable of interest is equal to one or zero for the dummy variables when the subindex is 1 or 0 , respectively. In the case of the categorical variables, the vector $X_{1}$ is substituted by its code. The marginal effects are calculated at the mean values of the sample. The practical implications of the formula are that the marginal effects of one variable in the model depend on all the model parameters, the data and the outcome of interest.

\section{Results}

Initially, a homoscedastic Ordered Probit model was estimated using effects coding for all the categorical variables included in the model (see Table EA3 in the electronic appendix for the detailed results). Effects coding normalization is not as popular as dummy coding normalization, but it presents a number of advantages (Hensher et al., 2005) that are relevant in the study. First, it avoids the always tricky selection of the reference base of the dummy coding normalization. Second, the marginal effects for each of the outcomes and levels of the categorical variables are referred to the average of all the levels of each variable and 


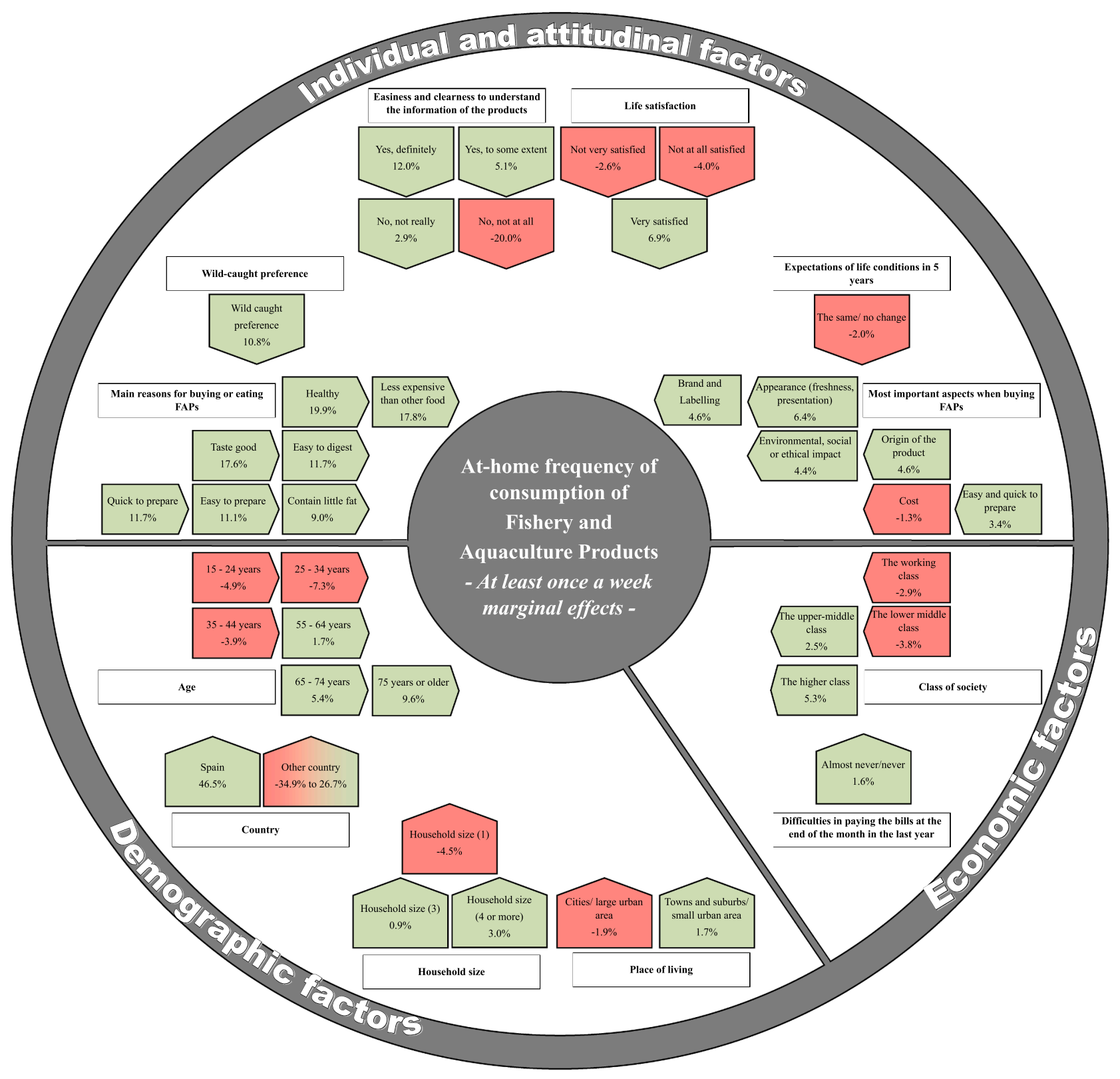

Fig. 1. Marginal effects for the consumption of FAPs at home at least once a week. 


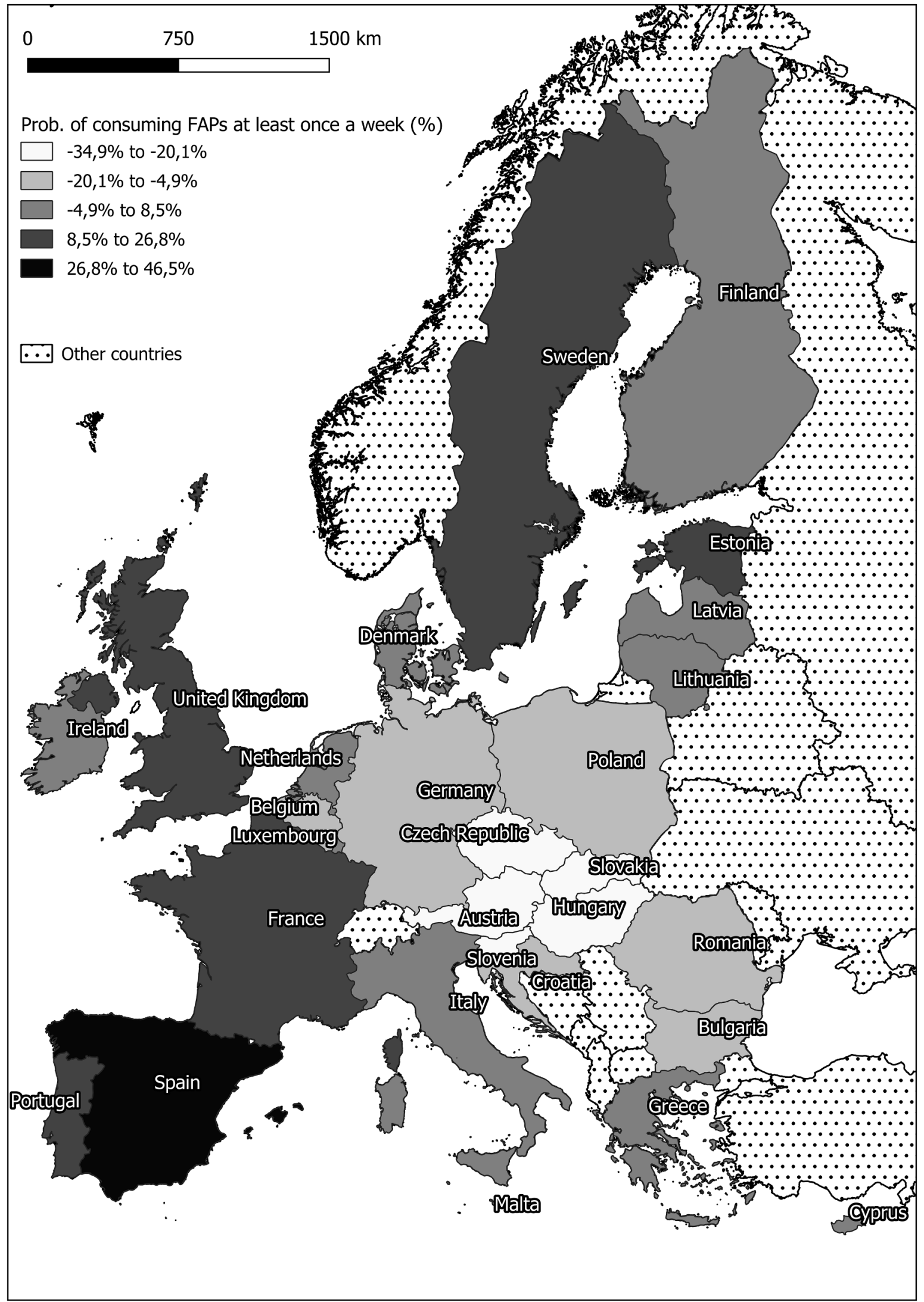

Fig. 2. Probabilities to eat FAPs at least once a week at home for the countries. 


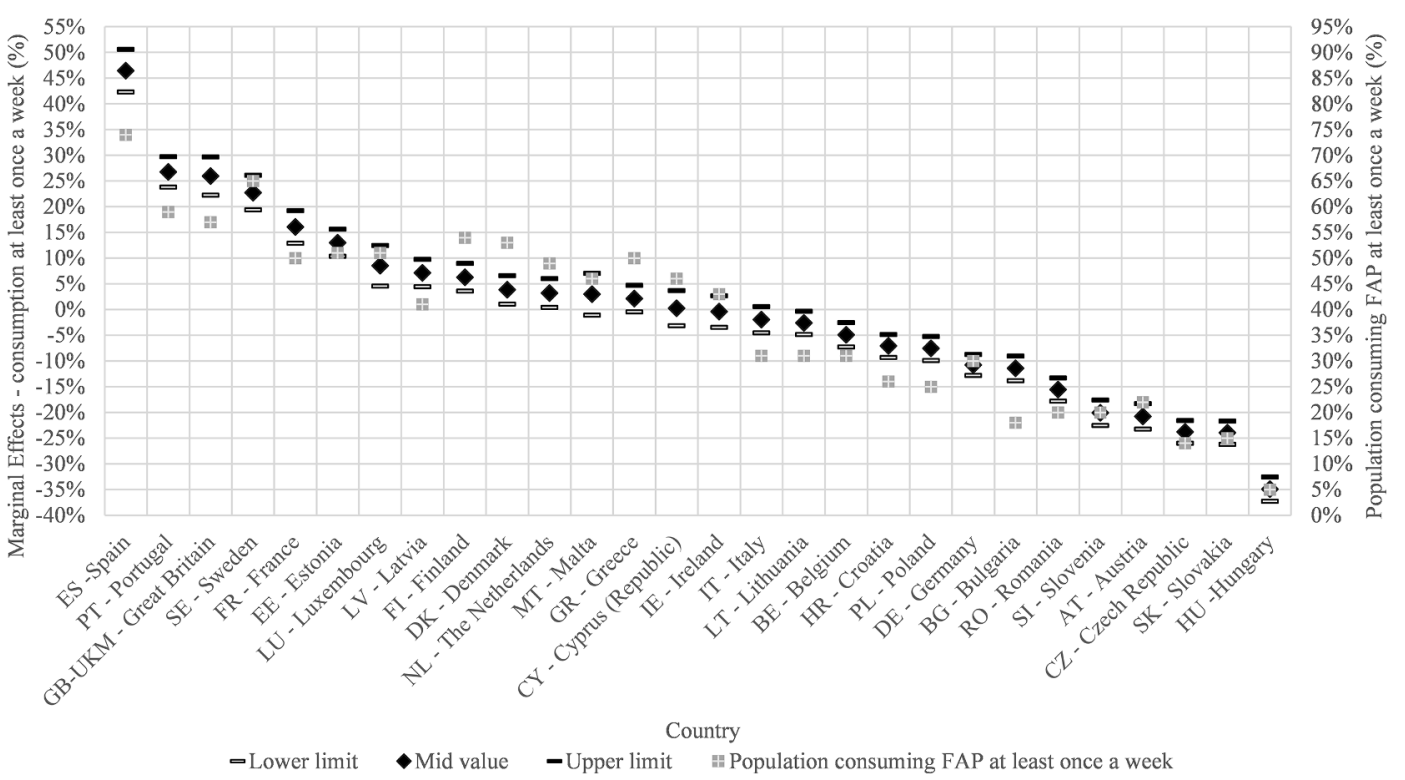

Fig. 3. Confidence intervals for the marginal effects of consuming fish at least once a week by country.

this is usually a better approach than an ex-ante selection of a specific category.

Results showed a significant and a higher frequency of consumption of FAPs for those consumers who: are older than 55 years, are part of the upper-middle class of society, have a wild product preference, live in a household of 3 persons or more, are very satisfied with their lives and never or rarely have difficulties paying the bills. Similarly, there is a consider that they are products for special occasions), as well as for those who contemplate as relevant any of the important aspects mentioned related to the product (except for the cost). In contrast, it was found that there is a lower frequency of consumption of FAPs for those consumers who: do not understand at all the information accompanying the products, are between the ages of 15 and 54 , live in cities or large urban areas, are not satisfied with their lives and expect no changes in their

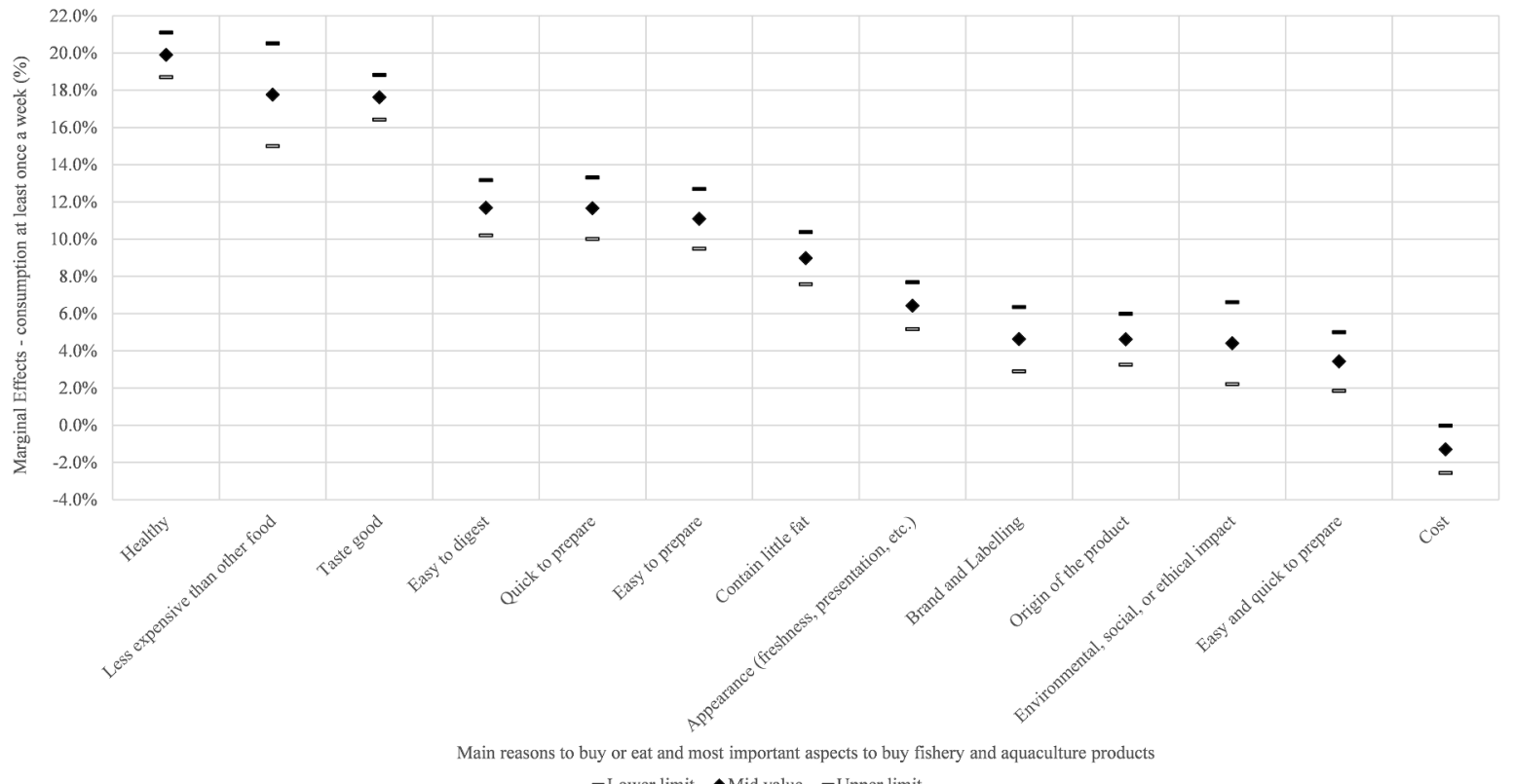

Fig. 4. Confidence intervals for the marginal effects of consuming fish at least once a week by the attitudes (reasons to buy or eat fish and aspects to buy fish).

higher frequency of consumption for consumers who select as important any of the reasons listed for buying the products (except for those who 

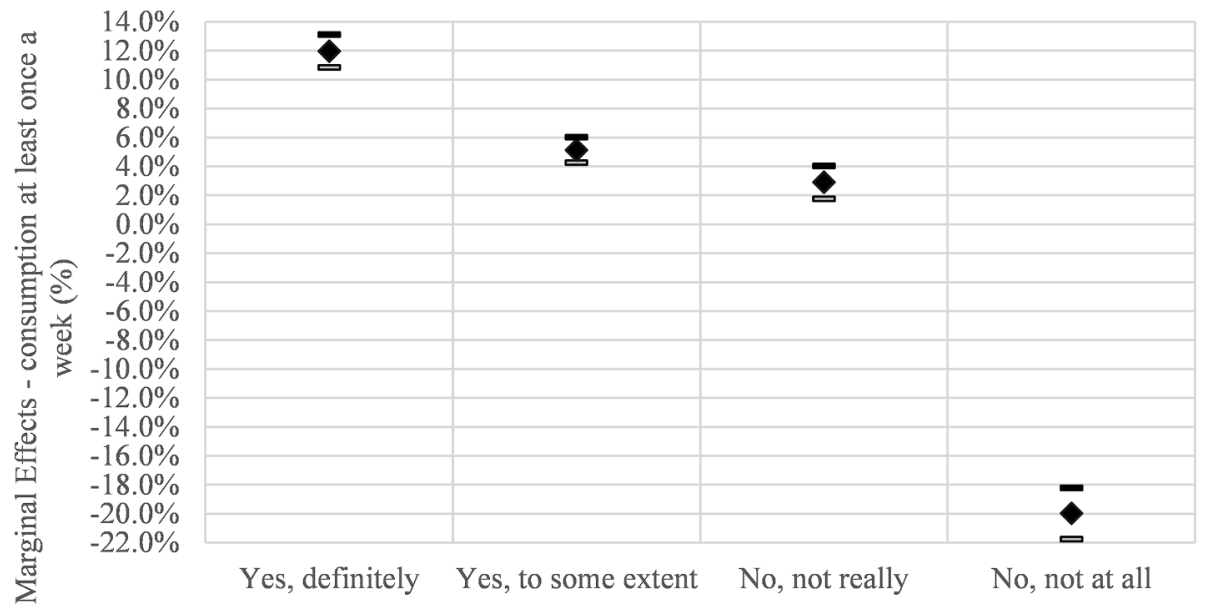

Level of understanding the information

- Lower limit

- Mid value -Upper limit

Fig. 5. Confidence intervals for the marginal effects of consuming fish at least once a week by the easiness to understand the information that accompanies fish products.

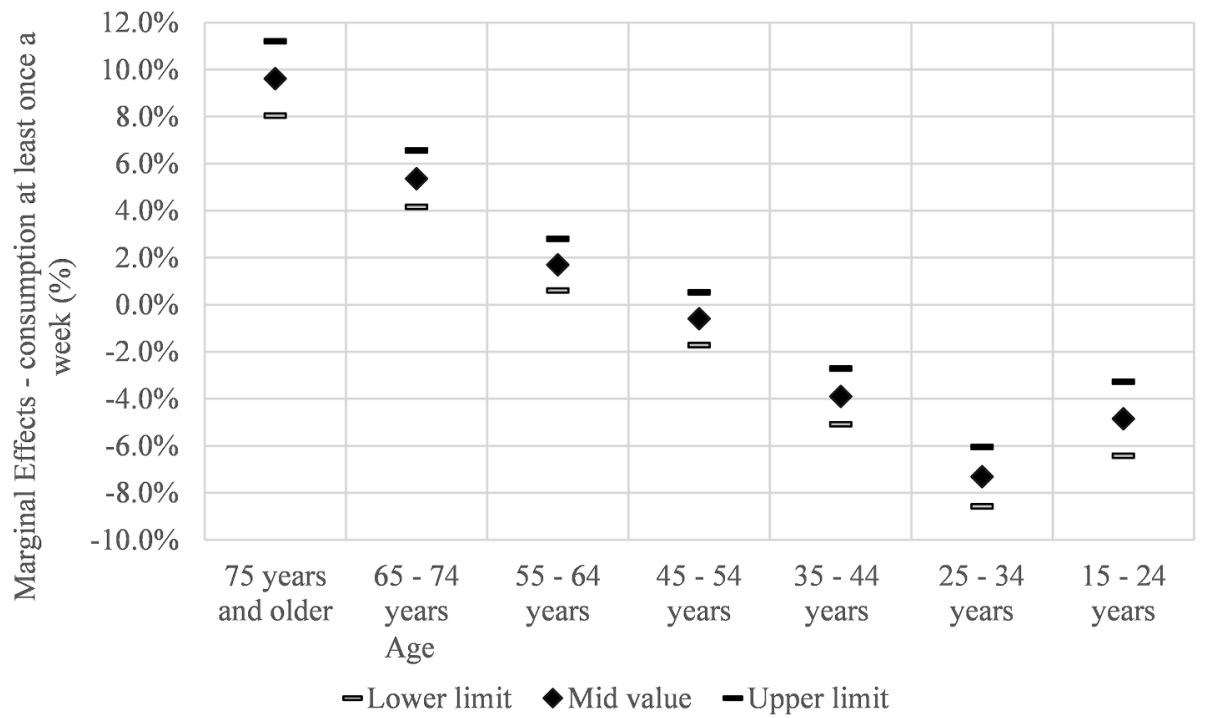

Fig. 6. Confidence intervals for the marginal effects of consuming fish at least once a week by age.

living conditions for the next five years.

After that, a heteroscedastic Ordered Probit model using effects coding (see Table EA3 in the electronic appendix for the detailed results) was estimated considering the same parameters, and it was found that, in many cases, the standard deviations of the factors could be explained by some of the factors included in the homoscedastic model. Thus, the homoscedasticity assumed in the homoscedastic model might lead to biased results for the obtained coefficients of some of the parameters. Furthermore, the heteroscedastic model showed a better adjustment than the homoscedastic model according to the Likelihood-ratio test. A more parsimonious heteroscedastic model was estimated considering just the parameters and standard deviations that were significant to a minimum significance level of 0.1 , while the rest were fixed to 0 . Nevertheless, the likelihood-ratio indicated that the fit of the model was lower than the previous model, so the first heteroscedastic ordered probit model was chosen to describe the results. Concretely, the analysis is focused on the marginal effects for the consumption frequency of at least once a week ${ }^{5}$.

\footnotetext{
${ }^{5}$ The rest of the marginal effects for the other consumption frequency levels are also available upon request.
} 
The marginal effects from the heteroscedastic model indicate that the frequency of consumption at home of FAPs differs across countries in the EU28. The largest marginal effects are observed in Spain, while Hungary presents the lowest marginal effects. Regarding the results on the main reasons for buying or eating fishery and aquaculture products, we obtain that the highest positive impact on the frequency of consumption is related to considering that FAPs are healthy, in contrast with other reasons such as the cost or the origin of the product. Another interesting issue to remark is that the most negative impact is related to not understanding at all the information accompanying the products. The marginal effects for the consumption of FAPs at home at least once a week are illustrated in Fig. 1 for the significant factors, in which the results are summarized succinctly according to the demographic factors (country of residence, age, place of living and household-size), the economic factors (difficulties in paying the bills and society class) and, individual and attitudinal factors (wild-caught preference, easiness and clearness to understand FAPs' information, main reasons for buying or eating FAPs, important aspects when buying FAPs, expectations of life conditions in five years and life satisfaction).

Results also show that attitudes of consumers towards the main reasons for buying or eating them are also very important determinants. Consumers who think that one of the main reasons for buying or eating FAPs is that they are less expensive than other foods, taste good, are easy to digest, are quick and easy to prepare or that they contain little fat, tend to consume them at home more frequently. In addition, less important factors to consume FAPs more frequently at home are related to those who believe that one of the most important aspects for buying FAPs refers to the product's appearance, the brand or quality labels, the origin of the product, the environmental, social or ethical impacts, or their easiness and quickness to prepare, also tend to consume the products more frequently. Interestingly, the cost result can be partly explained because it was only significant for the standard deviation, so, in general, it can be concluded that it is not relevant for the average consumer, but it might be important to some particular segments of the population.

The preference between wild and farmed products was found to be significant for the frequency of consumption of FAPs. The consumers who showed a clear preference for wild products were more eager to consume them more frequently. Besides, results indicate that the older generation of residents, especially those over 55 years old, are more eager to consume FAPs more frequently at home, as well as those living together with more people and in areas such as towns and suburbs or in small urban areas. Moreover, the results show a tendency for higher consumption rates for consumers who are part of higher social classes, while results also indicate that those who rarely or never had difficulties to pay their bills have a higher frequency of consumption of FAPs at home. It was also found that consumers who are not satisfied with their lives are less likely to eat FAPs at least once a week at home. Moreover, regarding the life condition expectations in five years, the results showed that those consumers who believe that their current living conditions will not change, tend to consume FAPs less frequently.

Analysing the probabilities to eat FAPs at least once a week at home for the countries according to their spatial distribution (see Fig. 2), it can be seen that countries which do not have a coastline or a very small one such as the Czech Republic, Slovakia, Hungary, Austria and Slovenia have the lowest values. Similarly, the countries on the western side of Europe, Sweden, Estonia and the United Kingdom have a higher probability of consuming FAPs more frequently than those on the eastern side of Europe.
We also present the $95 \%$ confidence intervals for the marginal effects' values of each one of the analysed parameters (the country's specific constants, the attitudes, the easiness to understand the information that accompanies the products and the age). Thus, it is possible to evaluate at first glance different pairwise comparisons. For example, the analysis of Fig. 3 indicated that the higher marginal effects mean values for the countries are observed in Spain, Portugal, Great Britain and Sweden. In general, the order of the countries according to the values of the parameters shows a similar tendency to their order according to the percentage of the population consuming FAPs at least once a week (European Union, 2018a), except for some specific cases.

Similarly, as shown in Fig. 4, the marginal effects' values for the attitudes towards eating or buying FAPs indicated that the most important reasons to eat or buy them were their healthiness, low relative cost and good taste, while the least important aspect was their specific cost. The marginal effects' values related to the levels of understanding the information accompanying the products are presented in Fig. 5, which exhibits that there is a high difference between the various levels of understanding the information accompanying the products and those who don't understand it at all. Finally, Fig. 6 shows the marginal effects' values of the age factor, which expose clearly that there is a tendency of higher consumption of FAPs for older consumers.

\section{Discussion}

Model results indicate that consumers who do not understand at all the information accompanying the products have a lower probability of around $20 \%$ to consume FAPs at least once a week than the average consumer. Therefore, the possibility of increasing the consumption of these products in the EU28 by simply providing clearer and easier to understand information can be considered an adequate policy to implement, especially, keeping in mind, that around $3 \%$ of respondents from the Eurobarometer survey indicated that the information accompanying FAPs was not at all clear or easy to understand (European Union, 2018a, 2018b). This strategy is also supported by several studies in the literature, which conclude that providing quality information to consumers enhances product attributes (Bronnmann and Hoffmann, 2018; Kumar, 2018).

Also, it was found that when consumers considered that the main reasons for buying FAPs are that they are healthy, less expensive than other foods and taste good, they have a higher probability of consuming FAPs at least once a week of $19.9 \%, 17.8 \%$ and $17.6 \%$, respectively. The results confirm the previous findings by Can et al. (2015), Murray et al. (2017) and Thong and Solgaard (2017), in which the authors found that there is a higher frequency of consumption for consumers who are concerned with health issues. Other studies have shown that consumers are willing to pay premiums for health-related labels on seafood products highlighting the content of Omega 3 (Banovic et al., 2019; Bi et al., 2016; Fernández-Polanco et al., 2013), the high content of protein (Banovic et al., 2019) or how the product improves heart (Banovic et al., 2019; Lim et al., 2018) and brain function (Banovic et al., 2019). Moreover, Thong and Solgaard (2017) also found that more frequent FAPs consumers were also characterized by those who considered the sensory qualities of FAPs to be important, such as the smell, texture, and taste.

In addition, our results indicate that other reasons that increase the probability of consuming FAPs at least once a week by around $11 \%$, are the consideration of the products as being easy to digest and easy or quick to prepare. This finding is consistent with Murray et al. (2017) and 
Thong and Solgaard (2017). In both papers, the authors found that there is a lower frequency of consumption for consumers who are uncomfortable cooking or preparing these products. For this reason, ready-tocook FAP's products can be considered an adequate policy that could promote the consumption of FAPs in the EU (Husein et al., 2020). Stead et al. (2004) warned that there are no simple solutions to those who are identified as feeling uncomfortable cooking FAPs, as the lack of confidence could be better aligned with unfamiliarity than with lack of cooking skills.

Other important individual and attitudinal determinants related to increasing the probability to consume FAPs at least once a week are: contain little fat $(9.0 \%)$, appearance -freshness and presentation(6.4\%), the brand and labelling (4.6\%), the origin of the product $(4.6 \%)$ and the environmental, social or ethical impacts (4.4\%). With regard to labels and environmental impacts, Almendarez-Hernández et al. (2017) and Santeramo et al. (2017) found that there is a higher frequency of consumption for consumers who care about eco-labels and environmental issues. In fact, some studies suggest that consumers are willing to pay premiums for products labelled as certified according to the standards of Aquaculture Stewardship Council (Banovic et al., 2019; Bronnmann and Asche, 2017; Bronnmann and Hoffmann, 2018; Hinkes and Schulze-Ehlers, 2018), Marine Stewardship Council (Bronnmann and Asche, 2017; Bronnmann and Hoffmann, 2018; Chen et al., 2015; Wakamatsu and Miyata, 2017) or Naturland (Hinkes and SchulzeEhlers, 2018), or labelled as produced with a more sustainable alternative process such as Integrated Multitrophic Aquaculture or Closed Containment Aquaculture (Yip et al., 2017). Concerning the appearance (freshness, presentation, etc), Almendarez-Hernández et al. (2017), Can et al. (2015), Hall and Amberg (2013), Kumar et al. (2008) and Yousuf et al. (2019) found similar results for fresh products, with higher consumer consumption rates than other presentations. Other studies have stated that consumers are willing to pay more for fresh seafood presentations than for other frozen presentations (Ankamah-Yeboah et al., 2019, 2018; Bronnmann and Asche, 2017; Davidson et al., 2012), while specifically for farmed salmon, consumers are willing to pay more for redder colour options, even after knowing that the red colour is artificially added (Alfnes et al., 2006; Olesen et al., 2010, 2006; Steine et al., 2005). Moreover, other studies have found that fillet presentation is preferred over whole fish (Ankamah-Yeboah et al., 2019, 2018) and steak (Thong et al., 2015) presentations.

In addition, according to the literature, the origin of the product is also an important determinant for consumers' decisions on seafood, with consumers having a higher willingness to pay for domestic or local products than for imported products (Ankamah-Yeboah et al., 2019, 2018; Ariji, 2010; Davidson et al., 2012; Fernández-Polanco et al., 2013; Hinkes and Schulze-Ehlers, 2018; Lim et al., 2018; Mauracher et al., 2013; Rudd et al., 2011; Stefani et al., 2012; Thong et al., 2015; Uchida et al., 2014; van Osch et al., 2019, 2017; Witkin et al., 2015).

Furthermore, with regard to environmental, social and ethical impacts, according to Schlag and Ystgaard (2013), European consumers are very concerned about the environmental impact of both wild and farmed fish. For example, Bronnmann and Hoffmann (2018) found that the environmental conditions of seafood products have an impact on consumers' choices and that consumers' preference for wild products was partially related to the negative environmental impact of farmed products. In fact, some studies have found that consumers are willing to pay premiums for environmentally friendly products (Fonner and Sylvia, 2015; Hynes et al., 2019; Lim et al., 2018; Olesen et al., 2010, 2006; Rudd et al., 2011). On the other hand, lower importance is given to social and ethical issues. For example, in Germany, Hinkes and SchulzeEhlers (2018) found that although consumers are willing to pay premiums for generic fair trade labels, they are willing to pay more for other certifications who focus more on environmental aspects such as the certifications by the Aquaculture Stewardship Council and Naturland.

All of these findings can be used by different stakeholders, mainly retailers, producers and policy-makers, to promote FAPs' consumption in the EU highlighting the healthiness, the taste of the products, the cheaper protein ingest in comparison with other foods and the ease of digestion. The retailers and the food industry should provide products that are easy and quick to prepare, as this strategy is not currently so common on the market in comparison with other food categories. Other less important determinants that could be improved are the appearance of the products, as well as the provision of clearer information regarding the origin, quality labels, and environmental, social, and ethical impacts. It is important to note that the information about the quality of the products, environmental, social, and ethical impacts may be added as voluntary labels as long as they comply with article 39 of the 1379/2013 EU regulation.

Moreover, regarding the distinction between farmed and wild products, consumers who prefer wild-caught products have a higher probability of $10.8 \%$ to eat them at least once a week. As a matter of fact, many investigations have shown that consumers are willing to pay more for wild-caught fish over farmed fish (Ariji, 2010; Bronnmann and Asche, 2017; Bronnmann and Hoffmann, 2018; Darko et al., 2016; Davidson et al., 2012; Fernández-Polanco et al., 2013; Roheim et al., 2012; Thong et al., 2015; Uchida et al., 2014). This finding reaffirms how important is the inclusion of the production method (wild-caught or farmed) as mandatory information for FAPs in the 1379/2013 EU regulation. Besides, this preference for wild-caught products is in line with the investigation of Murray et al. (2017) and exhibits a handicap that aquaculture producers and authorities need to correct by designing planned programs that can change the negative image of aquaculture products (Bronnmann and Hoffmann, 2018). In fact, several studies indicate that consumers describe farmed fish as less healthy and of lower quality when compared to wild fish (Claret et al., 2014; Verbeke et al., 2007). On the other hand, some studies have found that the key elements that conditioned the image and acceptance of the reared fish were the comparatively low costs, the perception of being an artificial product and the lack of information regarding sustainable breeding techniques (Altintzoglou et al., 2010; Claret et al., 2014; Vanhonacker et al., 2011).

Consumers between 65 and 74 years old (baby-boomers' generation) or over 75 years old have an increased probability of at least $5.4 \%$ and $9.6 \%$, respectively to consume FAPs at home at least once a week. Given that young people have a lower frequency of consumption at home for these products, strategies such as product differentiation, online shopping of ready-to-eat or ready-to-cook FAPs may increase their interests. Some studies in the literature found similarly a higher frequency of consumption for older consumers (Herrmann et al., 1994; Murray et al., 2017; Myrland et al., 2000; Thong and Solgaard, 2017).

Results also show that consumers with a household size of 3 persons or more are more likely to consume FAPs more frequently. The same result was also found by Islam et al. (2018), Myrland et al. (2000) and Yousuf et al. (2019). Our results also show that there is a higher frequency of FAPs consumption for those who have a better financial situation (social class equal or higher than the upper-middle class, and rarely or never have difficulties to pay their bills). This result is due to the fact that FAPs are normal goods and is consistent with the investigations of Can et al. (2015), Cavaliere et al. (2019), Herrmann et al. (1994), Lee and Nam (2019), Thong and Solgaard (2017) and Yousuf et al. (2019).

\section{Conclusions}

The results provide valuable information for different stakeholders such as fisheries, fish farms managers, retailers, food industry and policy-makers, which can be used for production improvement, marketing, and policy analysis. The use of an adequate representative database enhances the robustness and credibility of the results.

The greatest negative marginal effect on the frequency of home consumption of FAPs correspond to not understanding at all the information accompanying the products. Despite this, further analysis is required to confirm if this result is rather due to not actually paying 
attention to the mandatory information provided by the labels, instead of not really understanding it. For example, some consumers may have never read the labels, either because they could have good knowledge of FAPs based on childhood habits or because they could trust the suggestions made by local fishmongers. Additional studies are therefore needed to understand how information can be provided in a more attractive, clearer and easier way and to identify the information needed by consumers, to analyze and confirm the effectiveness of the current mandatory information set out in Article 39 of the EU Regulation 1379/ 2013.

The findings also highlight the importance of certain attitudes that increase the consumption frequency at the home for FAPs. These attitudes suggest that one of the main reasons for buying or eating FAPs is that they are healthy, less expensive than other foods, taste good, easy to digest, quick and easy to prepare and contain little fat. Similarly, other attitudes related important aspects for buying fish product such as the easiness and quickness to prepare, the product's origin, the product's appearance, the brand or quality labels, and the environmental, social or ethical impacts, also increase the consumption frequency but are less important than the previous ones. Results also indicate that FAPs are more frequently consumed by those who: prefer wild-caught products; are older than 55 years old; live in larger households; have a better financial situation, are very satisfied with their lives and live in towns and suburbs or small urban areas. It is also important to note that since the attitude towards the importance of the cost was not significant in general, but only for certain groups, producers should risk on looking for higher quality products that might be more attractive to some consumers despite their higher costs. However, before this, studies that evaluate the willingness to pay for these new products should be performed to understand the products' market feasibility and the population that might be interested in the product.

The study is not exempt from limitations. As mentioned in the methodology section, the heteroscedastic ordered probit model could be extended to account for unobserved heterogeneity. For example, the zero-inflated ordered probit model with its two-steps structure of a binary probit component and an ordered probit component could be proposed to analyse the two underlying states (no fish consumption vs. fish consumption). It is not unrealistic to suppose that these two states could greatly differ between countries. This model has been successfully applied in the analysis of low and severe accidents by Fountas et al. (2020). In addition, the systematic variation could also be analysed using sub-samples of the consumer population (grouped effects). For example, the effects of countries or other systematic geographical effects are likely to occur because consumers can share some cultural background regarding fish consumption. To that end, a grouped latent class ordered probit model with class-probability functions can be used to study the determinants that affect fish consumption at home in the EU. This type of models has been used by Fountas et al. (2018) to compare two latent class models (one based on segments and other based on accidents) that analyse the vehicle accident-injury severities in the state of Washington. Nevertheless, a word of caution for the search of more sophisticated models that better accommodate the unobserved heterogeneity is needed here as the payoff is usually manifested in terms of the difficulties in interpreting the parameters. Thus, a better model fit is usually accompanied by an arduous task of interpreting the results into something meaningful to describe the behaviour of fish consumption at home.

\section{Funding}

This work is part of a project that has received funding from the European Union's Horizon 2020 research and innovation programme under the Marie Skłodowska-Curie grant agreement No. 766347.

\section{CRediT authorship contribution statement}

Javier Cantillo: Conceptualization, Methodology, Software, Formal analysis, Writing - original draft, Visualization. Juan Carlos Martín: Conceptualization, Methodology, Software, Validation, Formal analysis, Writing - review \& editing, Supervision. Concepción Román: Conceptualization, Methodology, Software, Validation, Formal analysis, Writing - review \& editing, Supervision.

\section{Appendix A}

Tables 1 and 2

Table 1

Economic and demographic factors.

\begin{tabular}{|c|c|c|}
\hline Factor & Frequency trend & Supporting studies \\
\hline \multirow[t]{2}{*}{ Gender } & Higher frequency of consumption for women & Can et al., 2015; Cavaliere et al., 2019; Thong and Solgaard, 2017 \\
\hline & Higher frequency of consumption for men & Islam et al., 2018 \\
\hline \multirow[t]{2}{*}{ Age } & Higher frequency of consumption for older people & $\begin{array}{l}\text { Herrmann et al., 1994; Murray et al., 2017; Myrland et al., 2000; Thong and Solgaard, } \\
2017\end{array}$ \\
\hline & Higher frequency of consumption for younger people & Can et al., 2015; Cavaliere et al., 2019 \\
\hline \multirow[t]{2}{*}{ Household size } & $\begin{array}{l}\text { Higher frequency of consumption for a larger household } \\
\text { size }\end{array}$ & Myrland et al., 2000; Yousuf et al., 2019 \\
\hline & $\begin{array}{l}\text { Higher frequency of consumption for a shorter household } \\
\text { size }\end{array}$ & Islam et al., 2018; Thong and Solgaard, 2017 \\
\hline \multirow[t]{2}{*}{ Presence of young children } & Higher frequency of consumption & Myrland et al., 2000; Terin, 2019; Thong and Solgaard, 2017 \\
\hline & Lower frequency of consumption & Herrmann et al., 1994 \\
\hline \multirow[t]{2}{*}{ Education level } & $\begin{array}{l}\text { Higher frequency of consumption for a higher education } \\
\text { level }\end{array}$ & Can et al., 2015; Cavaliere et al., 2019; Islam et al., 2018; Myrland et al., 2000 \\
\hline & $\begin{array}{l}\text { Higher frequency of consumption for a lower education } \\
\text { level }\end{array}$ & Yousuf et al., 2019 \\
\hline \multirow[t]{2}{*}{ Income } & Higher frequency of consumption for a higher income & $\begin{array}{l}\text { Can et al., 2015; Cavaliere et al., 2019; Herrmann et al., 1994; Lee and Nam, 2019; } \\
\text { Terin, 2019; Thong and Solgaard, 2017; Yousuf et al., } 2019\end{array}$ \\
\hline & Higher frequency of consumption for a lower income & Almendarez-Hernández et al., 2017 \\
\hline \multirow[t]{2}{*}{$\begin{array}{l}\text { Married or living with } \\
\text { partner or family }\end{array}$} & $\begin{array}{l}\text { Higher frequency of consumption for being married or } \\
\text { living with a partner or family }\end{array}$ & Cavaliere et al., 2019; Kumar et al., 2008; Thong and Solgaard, 2017 \\
\hline & Higher frequency of consumption for being single & Can et al., 2015 \\
\hline Social class & Higher frequency of consumption for a higher social class & Islam et al., 2018 \\
\hline Household head & $\begin{array}{l}\text { Higher frequency of consumption in the respondent of the } \\
\text { survey is the head of the household }\end{array}$ & Terin, 2019 \\
\hline Household head working & $\begin{array}{l}\text { Higher frequency of consumption if the head of the } \\
\text { household works }\end{array}$ & Terin, 2019 \\
\hline
\end{tabular}


Table 2

Individual and attitudinal factors and product attributes.

\begin{tabular}{|c|c|c|}
\hline Factor & Frequency trend & Supporting studies \\
\hline $\begin{array}{l}\text { Attitude or favourability toward } \\
\text { seafood products }\end{array}$ & $\begin{array}{l}\text { Higher frequency of consumption for a positive attitude or favourability } \\
\text { toward seafood products }\end{array}$ & Kumar et al., 2008; Lee and Nam, 2019 \\
\hline Product presentation & $\begin{array}{l}\text { Higher frequency of consumption for consumers who prefer fresh products } \\
\text { over other presentations }\end{array}$ & $\begin{array}{l}\text { Almendarez-Hernández et al., 2017; Can et al., 2015; } \\
\text { Kumar et al., 2008; Yousuf et al., } 2019\end{array}$ \\
\hline Freshness & Higher frequency of consumption for a higher freshness of the product & Hall and Amberg, 2013; Kumar et al., 2008 \\
\hline Ecolabels and environmental issues & $\begin{array}{l}\text { Higher frequency of consumption for consumers who care about eco-labels } \\
\text { and environmental issues }\end{array}$ & $\begin{array}{l}\text { Almendarez-Hernández et al., 2017; Santeramo et al., } \\
2017\end{array}$ \\
\hline $\begin{array}{l}\text { Habitual consumers or being used to } \\
\text { eating the product }\end{array}$ & $\begin{array}{l}\text { Higher frequency of consumption for habitual consumers or who are used to } \\
\text { eat some seafood products }\end{array}$ & Santeramo et al., 2017; Yousuf et al., 2019 \\
\hline $\begin{array}{l}\text { Weight control (low calories and low } \\
\text { fat) }\end{array}$ & $\begin{array}{l}\text { Higher frequency of consumption for consumers that value as important that } \\
\text { the seafood products have low calories and fat }\end{array}$ & Thong and Solgaard, 2017 \\
\hline \multirow[t]{2}{*}{ Safety } & $\begin{array}{l}\text { Higher frequency of consumption for consumers who are satisfied with the } \\
\text { safety of the product }\end{array}$ & Lee and Nam, 2019 \\
\hline & $\begin{array}{l}\text { Higher frequency of consumption for consumers who care about the safety of } \\
\text { oysters and are experts on judging its safety }\end{array}$ & Santeramo et al., 2017 \\
\hline Recreational fish participation & $\begin{array}{l}\text { Higher frequency of consumption for consumers who are involved in } \\
\text { recreational fish activities }\end{array}$ & Herrmann et al., 1994 \\
\hline $\begin{array}{l}\text { Lifestyle-related to the level of } \\
\text { physical activity }\end{array}$ & $\begin{array}{l}\text { Higher frequency of consumption for consumers who execute physical } \\
\text { activities more often }\end{array}$ & Myrland et al., 2000 \\
\hline Childhood consumption & $\begin{array}{l}\text { Higher frequency of consumption as adults for consumers who consume } \\
\text { seafood frequently when they were children }\end{array}$ & Murray et al., 2017 \\
\hline $\begin{array}{l}\text { Subjective knowledge related to } \\
\text { seafood production }\end{array}$ & $\begin{array}{l}\text { Higher frequency of consumption at home for more knowledgeable } \\
\text { consumers }\end{array}$ & Almeida et al., 2015 \\
\hline Price or cost & Lower frequency of consumption for a higher price or cost & $\begin{array}{l}\text { Hall and Amberg, 2013; Lee and Nam, 2019; Terin, 2019; } \\
\text { Thong and Solgaard, } 2017\end{array}$ \\
\hline Inconvenience & $\begin{array}{l}\text { Lower frequency of consumption for consumers who are uncomfortable } \\
\text { cooking or preparing seafood }\end{array}$ & Murray et al., 2017; Thong and Solgaard, 2017 \\
\hline Wild vs. farmed seafood distinction & $\begin{array}{l}\text { Lower frequency of consumption for consumers who do not purchase wild } \\
\text { seafood }\end{array}$ & Murray et al., 2017 \\
\hline \multirow[t]{2}{*}{ Familiarity } & $\begin{array}{l}\text { Higher frequency of consumption for consumers who are familiar with } \\
\text { aquaculture products }\end{array}$ & Hall and Amberg, 2013 \\
\hline & $\begin{array}{l}\text { Lower frequency of consumption of shrimp and mussel for consumers who } \\
\text { give importance to the familiarity of the food }\end{array}$ & Thong and Solgaard, 2017 \\
\hline \multirow[t]{2}{*}{ Health } & $\begin{array}{l}\text { Higher frequency of consumption for consumers who care about health issues } \\
\text { of the product }\end{array}$ & $\begin{array}{l}\text { Can et al., 2015; Murray et al., 2017; Thong and Solgaard, } \\
2017\end{array}$ \\
\hline & $\begin{array}{l}\text { Lower frequency of consumption for consumers who care about health issues } \\
\text { of the product }\end{array}$ & Santeramo et al., 2017 \\
\hline \multirow[t]{2}{*}{$\begin{array}{l}\text { Sensory qualities (smell, texture, } \\
\text { taste) }\end{array}$} & $\begin{array}{l}\text { Higher frequency of consumption for consumers who consider important the } \\
\text { sensory quality of the product }\end{array}$ & Thong and Solgaard, 2017 \\
\hline & Lower frequency of consumption for consumers who value oysters as tasty & Santeramo et al., 2017 \\
\hline Other seafood consumption & $\begin{array}{l}\text { Higher frequency of consumption for consumers that eat other aquaculture } \\
\text { products apart from fish }\end{array}$ & Terin, 2019 \\
\hline
\end{tabular}

\section{Appendix B. Supplementary data}

Supplementary data to this article can be found online at https://doi. org/10.1016/j.foodqual.2020.104085.

\section{References}

Alfnes, F., Guttormsen, A. G., Steine, G., \& Kolstad, K. (2006). Consumers' willingness to pay for the color of salmon: A choice experiment with real economic incentives. American Journal of Agricultural Economics, 88, 1050-1061. https://doi.org/ 10.1111/j.1467-8276.2006.00915.x

Almeida, C., Altintzoglou, T., Cabral, H., \& Vaz, S. (2015). Does seafood knowledge relate to more sustainable consumption? British Food Journal, 117(2), 894-914.

Almendarez-Hernández, M. A. A., Avilés-Polanco, G., Beltrán-Morales, L. F., \& PérezRamirez, M. Y. (2017). Determinantes en el consumo de atún en México aplicando modelos de elección ordenada. Interciencia.

Altintzoglou, T., Verbeke, W., Vanhonacker, F., \& Luten, J. (2010). The image of fish from aquaculture among Europeans: Impact of exposure to balanced information. Journal of Aquatic Food Product Technology, 19(2), 103-119.

Ankamah-Yeboah, I., Jacobsen, J. B., \& Olsen, S. B. (2018). Innovating out of the fishmeal trap: The role of insect-based fish feed in consumers' preferences for fish attributes. British Food Journal, 120(10), 2395-2410.

Ankamah-Yeboah, I., Jacobsen, J. B., Olsen, S. B., Nielsen, M., \& Nielsen, R. (2019). The impact of animal welfare and environmental information on the choice of organic fish: An empirical investigation of German trout consumers. Marine Resource Economics, 34(3), 247-266.

Ariji, M. (2010). Conjoint analysis of consumer preference for bluefin tuna. Fisheries Science, 76(6), 1023-1028.

Avsar, G., Ham, R., \& Tannous, W. K. (2017). Factors influencing the incidence of obesity in Australia: A generalized ordered probit model. Int J Environ Res Public Health, 14. https://doi.org/10.3390/ijerph14020177
Bago d'Uva, T. (2005). Latent class models for use of primary care: evidence from a British panel. Health Econ, 14, 873-892. https://doi.org/10.1002/hec.1047

Banovic, M., Reinders, M. J., Claret, A., Guerrero, L., \& Krystallis, A. (2019). A crosscultural perspective on impact of health and nutrition claims, country-of-origin and eco-label on consumer choice of new aquaculture products. Food Research International, 123, 36-47.

Behnood, A., \& Mannering, F. (2017). Determinants of bicyclist injury severities in bicycle-vehicle crashes: A random parameters approach with heterogeneity in means and variances. Analytic Methods in Accident Research, 16, 35-47.

Bi, X., House, L., \& Gao, Z. (2016). Impacts of nutrition information on choices of fresh seafood among parents. Marine Resource Economics, 31(3), 355-372.

Bronnmann, J., \& Asche, F. (2017). Sustainable Seafood From Aquaculture and Wild Fisheries: Insights From a Discrete Choice Experiment in Germany. Ecological Economics, 142, 113-119.

Bronnmann, J., \& Hoffmann, J. (2018). Consumer preferences for farmed and ecolabeled turbot: A North German perspective. Aquaculture Economics \& Management, 22(3), 342-361.

Can, M. F., Günlü, A., \& Can, H. Y. (2015). Fish consumption preferences and factors influencing it. Journal of Food Science and Technology (Campinas), 35, 339-346. https://doi.org/10.1590/1678-457X.6624

Cavaliere, A., De Marchi, E., Donzelli, F., \& Banterle, A. (2019). Is the Mediterranean Diet for all? An analysis of socioeconomic inequalities and food consumption in Italy. British Food Journal. https://doi.org/10.1108/BFJ-06-2018-0373

Chen, X., Alfnes, F., \& Rickertsen, K. (2015). Consumer preferences, ecolabels, and effects of negative environmental information. AgBioForum, 18, 327-336.

Claret, A., Guerrero, L., Ginés, R., Grau, A., Hernández, M. D., Aguirre, E., Peleteiro, J. B., Fernández-Pato, C., \& Rodríguez-Rodríguez, C. (2014). Consumer beliefs regarding farmed versus wild fish. Appetite, 79, 25-31.

Cubas-Díaz, M., Martínez Sedano, M.Á., 2018. Do Credit Ratings Take into Account the Sustainability Performance of Companies? Sustainability 10, 4272. https://doi.org/ 10.3390/su10114272.

D'Amico, P., Armani, A., Gianfaldoni, D., Guidi, A., 2016. New provisions for the labelling of fishery and aquaculture products: Difficulties in the implementation of 
Regulation (EU) n. 1379/2013. Marine Policy 71, 147-156. https://doi.org/ 10.1016/j.marpol.2016.05.026.

Darko, F. A., Quagrainie, K. K., \& Chenyambuga, S. (2016). Consumer preferences for farmed tilapia in Tanzania: A choice experiment analysis. Journal of Applied Aquaculture, 28(3), 131-143.

Davidson, K., Pan, M., Hu, W., \& Poerwanto, D. (2012). Consumers' willingness to pay for aquaculture fish products vs. wild-caught seafood - a case study in Hawaii. Aquaculture Economics \& Management, 16, 136-154. https://doi.org/10.1080/ 13657305.2012 .678554

European Commission, 2019. Eurobarometer 89.3 (2018). Kantar Public [producer]. GESIS Data Archive, Cologne. ZA7483 Data file Version 1.0.0. https://doi.org/doi. org $/ 10.4232 / 1.13212$.

European Commission, 2017. EU consumer habits regarding fishery and aquaculture products . Annex 3, Mapping of national campaigns. (Website). Publications Office of the European Union.

European Commission, 2016. Market organisation [WWW Document]. Fisheries European Commission. URL https://ec.europa.eu/fisheries/cfp/market_en (accessed 4.28.20).

European Parliament, 2013. Regulation (EU) No 1379/2013 of the European Parliament and of the Council of 11 December 2013 on the common organisation of the markets in fishery and aquaculture products, amending Council Regulations (EC) No 1184/ 2006 and (EC) No 1224/2009 and repealing Council Regulation (EC) No 104/2000, OJ L.

European Union, 2018a. Special Eurobarometer 475: EU consumer habits regarding fishery and aquaculture products.

European Union, 2018b. The EU Fish Market - 2018 Edition.

FAO, 2018. FAO yearbook. Fishery and aquaculture statistics 2016. FOOD \& AGRICULTURE ORG, Rome, Italy.

FAO, n.d. Fish and human nutrition.

Fernández-Polanco, J., Loose, S. M., \& Luna, L. (2013). Are retailers' preferences for seafood attributes predictive for consumer wants? Results from a choice experiment for seabream (Sparus aurata). Aquaculture Economics \& Management, 17(2), 103-122.

Fonner, R., \& Sylvia, G. (2015). Willingness to pay for multiple seafood labels in a niche market. Marine Resource Economics, 30(1), 51-70.

Fountas, G., Anastasopoulos, P.Ch., 2018. Analysis of accident injury-severity outcomes: The zero-inflated hierarchical ordered probit model with correlated disturbances. Analytic Methods in Accident Research 20, 30-45. https://doi.org/10.1016/j. amar.2018.09.002.

Fountas, G., \& Anastasopoulos, P. C. (2017). A random thresholds random parameters hierarchical ordered probit analysis of highway accident injury-severities. Analytic Methods in Accident Research, 15, 1-16.

Fountas, G., Anastasopoulos, P. C., \& Mannering, F. L. (2018). Analysis of vehicle accident-injury severities: A comparison of segment- versus accident-based latent class ordered probit models with class-probability functions. Analytic Methods in Accident Research, 18, 15-32.

Fountas, G., Fonzone, A., Gharavi, N., \& Rye, T. (2020). The joint effect of weather and lighting conditions on injury severities of single-vehicle accidents. Analytic Methods in Accident Research, 27, 100124. https://doi.org/10.1016/j.amar.2020.100124

Greene, W. H., \& Hensher, D. A. (2010). Modeling ordered choices: A primer. Cambridge: Cambridge University Press. https://doi.org/10.1017/CBO9780511845062.

Greene, W. H., Harris, N. M., Hollingworth, B., \& Maitra, P. (2008). A bivariate latent class correlated generalized ordered probit model with an application to modeling observed obesity levels (SSRN Scholarly Paper No. ID 1281910). Rochester, NY: Social Science Research Network.

Hall, T. E., \& Amberg, S. M. (2013). Factors influencing consumption of farmed seafood products in the Pacific northwest. Appetite, 66, 1-9.

Hensher, D.A., Rose, J.M., Greene, W.H., 2005. Applied Choice Analysis | Applied Choice Analysis, A Primer.

Herrmann, R. O., Rauniyar, G. P., Hanson, G. D., \& Wang, G. (1994). Identifying frequent seafood purchasers in the Northeastern U.S. Agricultural and Resource Economics Review, 23(2), 226-235.

Higuchi, A., Dávalos, J., Hernani-Merino, M., Higuchi, A., Dávalos, J., \& HernaniMerino, M. (2017). Theory of planned behavior applied to fish consumption in modern Metropolitan Lima. Food Science and Technology, 37, 202-208. https://doi. org/10.1590/1678-457x.17516

Hinkes, C., \& Schulze-Ehlers, B. (2018). Consumer attitudes and preferences towards pangasius and tilapia: The role of sustainability certification and the country of origin. Appetite, 127, 171-181.

Husein, Y., Secci, G., Mancini, S., Zanoni, B., \& Parisi, G. (2020). Nutritional quality, physical properties and lipid stability of ready-to-cook fish products are preserved during frozen storage and oven-cooking. Journal of Aquatic Food Product Technology, 29(2), 207-217.

Hynes, S., Ravagnan, E., \& Gjerstad, B. (2019). Do concerns for the environmental credentials of salmon aquaculture translate into WTP a price premium for sustainably farmed fish? A contingent valuation study in Ireland and Norway. Aquaculture International, 27(6), 1709-1723.

Islam, M. J., Sayeed, M. A., Akhtar, S., Hossain, M. S., \& Liza, A. A. (2018). Consumers profile analysis towards chicken, beef, mutton, fish and egg consumption in Bangladesh. British Food Journal, 120(12), 2818-2831.

Jiang, Y., House, L. A., Kim, H., \& Percival, S. S. (2017). Zero-inflated ordered probit approach to modeling mushroom consumption in the United States. International Food and Agribusiness Management Review, 20(5), 655-672.

Kumar, G. (2018). Aquaculture production and marketing: A peek into the world of producers and consumers. Aquaculture Economics \& Management, 22(3), 279-283.
Kumar, G., Quagrainie, K., \& Engle, C. (2008). Factors that influence frequency of purchase of catfish by U.S. households in selected Cities. Aquaculture Economics \& Management, 12(4), 252-267.

Lee, M.-K., \& Nam, J. (2019). The determinants of live fish consumption frequency in South Korea. Food Research International, 120, 382-388.

Lim, K. H., Hu, W., \& Nayga, R. M., Jr. (2018). Is Marine Stewardship Council's ecolabel a rising tide for all? Consumers' willingness to pay for origin-differentiated ecolabeled canned tuna. Marine Policy, 96, 18-26.

Mauracher, C., Tempesta, T., \& Vecchiato, D. (2013). Consumer preferences regarding the introduction of new organic products. The case of the Mediterranean sea bass (Dicentrarchus labrax) in Italy. Appetite, 63, 84-91.

Murray, G., Wolff, K., \& Patterson, M. (2017). Why eat fish? Factors influencing seafood consumer choices in British Columbia, Canada. Ocean \& Coastal Management, 144, $16-22$.

Myrland, Øystein, Trondsen, T., Johnston, R. S., \& Lund, E. (2000). Determinants of seafood consumption in Norway: Lifestyle, revealed preferences, and barriers to consumption. Food Quality and Preference, 11(3), 169-188.

Olesen, I., Alfnes, F., Røra, M. B., \& Kolstad, K. (2010). Eliciting consumers' willingness to pay for organic and welfare-labelled salmon in a non-hypothetical choice experiment. Livestock Science, 127(2-3), 218-226.

Olesen, I., Alfnes, F., Rørå, M.B., Navrud, S., Kolstad, K., 2006. Economic values of fish welfare and application of market experiments, in: Ethics and the Politics of Food: Preprints of the 6th Congress of the European Society for Agricultural and Food Ethics. pp. 446-451. https://doi.org/10.3920/978-90-8686-575-8.

Pfarr, C., Schmid, A., Schneider, U., 2010. Estimating Ordered Categorical Variables Using Panel Data: A Generalized Ordered Probit Model with an Autofit Procedure (SSRN Scholarly Paper No. ID 1624954). Social Science Research Network, Rochester, NY. https://doi.org/10.2139/ssrn.1624954.

Pudney, S., \& Shields, M. (2000). Gender, race, pay and promotion in the British nursing profession: Estimation of a generalized ordered probit model. J. Appl. Econ., 15(4), 367-399.

Quagrainie, D. K. (2006). IQF catfish retail pack: A study of consumers' willingness to pay. International Food and Agribusiness Management Review, 9, 13.

Roheim, C. A., Sudhakaran, P. O., \& Durham, C. A. (2012). Certification of shrimp and salmon for best aquaculture practices: assessing consumer preferences in Rhode island. Aquaculture Economics \& Management, 16(3), 266-286.

Rortveit, A. W., \& Olsen, S. O. (2009). Combining the role of convenience and consideration set size in explaining fish consumption in Norway. Appetite, 52(2), 313-317.

Rortveit, A. W., \& Olsen, S. O. (2007). The role of consideration set size in explaining fish consumption. Appetite, 49(1), 214-222.

Rudd, M. A., Pelletier, N., \& Tyedmers, P. (2011). Preferences for health and environmental attributes of farmed salmon amongst southern Ontario salmon consumers. Aquaculture Economics \& Management, 15(1), 18-45.

Santeramo, F. G., Carlucci, D., De Devitiis, B., Nardone, G., \& Viscecchia, R. (2017). On consumption patterns in oyster markets: The role of attitudes. Marine Policy, 79, 54-61.

Katrin Schlag, A., \& Ystgaard, K. (2013). Europeans and aquaculture: Perceived differences between wild and farmed fish. British Food Journal, 115(2), 209-222.

Stead, M., Caraher, M., Wrieden, W., Longbottom, P., Valentine, K., \& Anderson, A. (2004). Confident, fearful and hopeless cooks: Findings from the development of a food-skills initiative. British Food Journal, 106(4), 274-287.

Stefani, G., Scarpa, R., \& Cavicchi, A. (2012). Exploring consumer's preferences for farmed sea bream. Aquaculture International, 20(4), 673-691.

Steine, G., Alfnes, F., \& Rørå, M. B. (2005). The Effect of Color on Consumer WTP for Farmed Salmon. Marine Resource Economics, 20(2), 211-219.

Stone, J., Goemans, C., Costanigro, M., 2019. Variation in Water Demand Responsiveness to Utility Policies and Weather: A Latent-Class Model. Water Econs. Policy 06, 1950006. https://doi.org/10.1142/S2382624X19500061.

Terin, M. (2019). Household characteristics influencing fish consumption in Van province, Turkey. Italian. Journal of Food Science, 31.

Thong, N. T., \& Olsen, S. O. (2012). Attitude toward and consumption of fish in Vietnam. Journal of Food Products Marketing, 18(2), 79-95.

Thong, N. T., \& Solgaard, H. S. (2017). Consumer's food motives and seafood consumption. Food Quality and Preference, 56, 181-188.

Thong, T.N., Haider, W., Solgaard, H.S., Ravn-Jonsen, L., Roth, E., 2015. Consumer willingness to pay for quality attributes of fresh seafood: A labeled latent class model. Food Quality and Preference 41, 225-236. https://doi.org/10.1016/j. foodqual.2014.12.007.

Tomić, M., Matulić, D., \& Jelić, M. (2016). What determines fresh fish consumption in Croatia? Appetite, 106, 13-22.

Tuu, H. H., Olsen, S. O., Thao, D. T., \& Anh, N. T. K. (2008). The role of norms in explaining attitudes, intention and consumption of a common food (fish) in Vietnam. Appetite, 51(3), 546-551.

Uchida, H., Onozaka, Y., Morita, T., \& Managi, S. (2014). Demand for ecolabeled seafood in the Japanese market: A conjoint analysis of the impact of information and interaction with other labels. Food Policy, 44, 68-76.

van Osch, S., Hynes, S., Freeman, S., O'Higgins, T., 2019. Estimating the Public's Preferences for Sustainable Aquaculture: A Country Comparison. Sustainability 11, 569. https://doi.org/10.3390/su11030569.

van Osch, S., Hynes, S., O'Higgins, T., Hanley, N., Campbell, D., Freeman, S., 2017. Estimating the Irish public's willingness to pay for more sustainable salmon produced by integrated multi-trophic aquaculture. Marine Policy 84, 220-227. https://doi.org/10.1016/j.marpol.2017.07.005. 
Vanhonacker, F., Altintzoglou, T., Luten, J., \& Verbeke, W. (2011). Does fish origin matter to European consumers?: Insights from a consumer survey in Belgium, Norway and Spain. British Food Journal, 113(4), 535-549.

Verbeke, W., Sioen, I., Brunsø, K., De Henauw, S., \& Van Camp, J. (2007). Consumer perception versus scientific evidence of farmed and wild fish: Exploratory insights from Belgium. Aquaculture International, 15(2), 121-136.

Verbeke, W., \& Vackier, I. (2005). Individual determinants of fish consumption: Application of the theory of planned behaviour. Appetite, 44(1), 67-82.

Wakamatsu, H., \& Miyata, T. (2017). Reputational damage and the Fukushima disaster: An analysis of seafood in Japan. Fisheries Science, 83(6), 1049-1057.

Winkelmann, R., \& Boes, S. (2009). Analysis of microdata (2nd ed.). Berlin Heidelberg: Springer-Verlag.
Witkin, T., Dissanayake, S. T. M., \& McClenachan, L. (2015). Opportunities and barriers for fisheries diversification: Consumer choice in New England. Fisheries Research, $168,56-62$.

Yip, W., Knowler, D., Haider, W., \& Trenholm, R. (2017). Valuing the willingness-to-pay for sustainable seafood: integrated multitrophic versus closed containment aquaculture: valuing the willingness-to-pay for sustainable seafood. Canadian Journal of Agricultural Economics/Revue canadienne d'agroeconomie, 65(1), 93-117. Yousuf, J. B., Bose, S., Kotagama, H., \& Boughanmi, H. (2019). Preferences and intentions of seafood consumers in Oman: An empirical analysis. Journal of International Food \& Agribusiness Marketing, 31(2), 175-203. 